\title{
Valorization of Hazelnut Shells as Growing Substrate for Edible and Medicinal Mushrooms
}

\author{
Federico Puliga *, ${ }^{+}$, Pamela Leonardi ${ }^{\dagger}$, Francesco Minutella, Alessandra Zambonelli (D) and Ornella Francioso ${ }^{D}$
}

Citation: Puliga, F.; Leonardi, P.; Minutella, F.; Zambonelli, A.; Francioso, O. Valorization of Hazelnut Shells as Growing Substrate for Edible and Medicinal Mushrooms. Horticulturae 2022, 8 , 214. https://doi.org/10.3390/ horticulturae 8030214

Academic Editor: Agnieszka Jasińska

Received: 11 February 2022

Accepted: 25 February 2022

Published: 28 February 2022

Publisher's Note: MDPI stays neutral with regard to jurisdictional claims in published maps and institutional affiliations.

Copyright: (C) 2022 by the authors. Licensee MDPI, Basel, Switzerland. This article is an open access article distributed under the terms and conditions of the Creative Commons Attribution (CC BY) license (https:// creativecommons.org/licenses/by/ $4.0 /)$.
Department of Agricultural and Food Sciences, University of Bologna, Viale G. Fanin 40-50, 40127 Bologna, Italy; pamela.leonardi@unibo.it (P.L.); francesco.minutella@studio.unibo.it (F.M.); alessandr.zambonelli@unibo.it (A.Z.); ornella.francioso@unibo.it (O.F.)

* Correspondence: federico.puliga2@unibo.it

+ These authors contributed equally to this work.

\begin{abstract}
Recently, the cultivation of hazel is undergoing a large expansion. Italy is the world's second largest producer of hazelnuts, with a production of around 98,530 tons in 2019. The processing of hazelnuts produces large amounts of waste, especially woody pericarps, due to the cracking process, generally used for domestic heating, causing air pollution. The high lignin content present in the pericarps makes them a suitable substrate for the cultivation of edible and medicinal mushrooms. To this aim, Ganoderma lucidum, Lentinula edodes, and Pleurotus cornucopiae were grown and cultivated on different hazelnut-shell-based substrates: Hazelnut Shell (HS), Hazelnut Shell and Wheat Straw (HS-WS), and Wheat Straw mixed with Beech Chips (WS-BC) as control. In vitro mycelial grow rate, the degradation capacity of the lignocellulosic fraction, the biological efficiency, and the qualitative differences between mushrooms growing on different substrates by using Attenuated Total Reflectance-Fourier transform infrared (ATR-FTIR) spectroscopy were investigated. Our results suggested the ability of G. lucidum, L. edodes, and P. cornucopiae to grow and decay the lignocellulosic fraction of HS. Cultivation trials showed a similar biological efficiency but a different Fruiting Body Production (FBP) in the presence of HS with respect to the control. ATR-FTIR analysis provided a chemical insight for the examined fruiting bodies, and differences were found among the substrates studied. These results provide attractive perspectives both for more sustainable management and for the improvement of mushroom cultivation efficiency.
\end{abstract}

Keywords: sustainability; mushroom cultivation; wood fungi; ATR-FTIR

\section{Introduction}

The hazel, Corylus avellana L., is the world's leading nut crop with a production of $1,125,178$ tons in 2019 [1]. Turkey, Italy, and Azerbaijan are the three lay producers with a production of 776,$046 ; 98,530$ and 53,793 tonnes, respectively [1]. Ninety percent of the hazelnuts produced are intended for processing [2], deprived of the woody pericarp, and used in chocolate, pastry, confectionery, as well as in the preparation of numerous foods and liqueurs $[3,4]$.

One of the main concerns associated with hazelnut production is due the large amount of by-products. Hazelnuts are mechanically collected by compact harvesters in-shell covered by husks that are mechanically separated during harvesting. In-shell nuts need to be opened in order to be introduced into the industrial food chain. The woody biomass produced as a result of the cracking process accounts for more than $50 \%$ of the total nut weight [5]. Lignin, present in a percentage between $40 \%$ and $50 \%$, is the main constituent of the hazelnut shells, followed by hemicellulose and cellulose present in percentages between 13-32 and 16-27 percent, respectively [5-7].

In recent years, there has been marked attention to climate change, the preservation of species biodiversity, environmental sustainability by sustainable and environmentally 
friendly use, and the recycling of waste in line with the circular economy approach. Consequently, the scientific community is encouraged to seek new methods and strategies for exploiting the by-products of agricultural activities.

Traditionally, hazelnut shells (HS) are mainly used as a boiler fuel for domestic heating causing air pollution [8-10] and for landscaping [11]. Several studies have been conducted in order to enhance and valorize this waste by-product with the aim to obtain new materials, chemical compounds, and bioactive ingredients. In particular, HS were found to be suitable for the production of particleboard and Medium Density Fiberboard (MDF) [12,13], activated carbons capable of adsorbing and removing different heavy metals and $\mathrm{CO}_{2}$ [14-22], antioxidant phenolics [6,23-26], fermentable sugars and xylooligosaccharides [11,27], hydrogen production [28,29], ethanol [30] and some prebiotic compounds [31].

Mushrooms are considered an important source of food and biologically active compounds with several medicinal proprieties [32]. Various lignocellulolytic mushrooms such as oyster mushrooms, shiitake, and Ganoderma sp. are cultivated on different pasteurized or sterilized lignocellulosic substrates. While oyster mushroom (Pleurotus spp.) and shiitake (Lentinula edodes (Berk.) Pegler) are cultivated worldwide for their culinary qualities [33,34], Ganoderma lucidum sensu latu is the most important medicinal mushroom, and it is specifically cultivated for its pharmacological activities [35]. Moreover, mushrooms can be cultivated on several agricultural wastes, which can be sustainably recycled in the principles of circular economy [36].

Some previous works report the possibility of using the hazelnut husk and hazelnut leaves as basal ingredients for substrate preparation in L. edodes and Pleurotus cultivation $[10,37,38]$, but no reference was found by the authors regarding the use of HS as substrate for mushroom cultivation. Due to the high lignin content, this by-product can be used as a substrate for the cultivation of lignocellulolytic mushrooms.

Fourier transform infrared spectroscopy (FTIR) is widely used for the rapid and non-destructive characterization of the macromolecule structures (lipids, proteins, nucleic acids, and polysaccharides) [39]. More specifically, amongst the various techniques used, attenuated total micro reflectance (ATR) is viewed as very advantageous as it doesn't require any sample preparation prior to spectral analysis. In ATR measurements, the depth of penetration of the IR radiation into the sample is independent of the sample thickness. Consequently, by layering the solid sample directly on the micro diamond crystal, structural information at different parts of the sample may be gained. Specifically, it was used to identify species and geographic origin of Boletus sp. mushrooms [40] or quantify the total polysaccharide content in Ganoderma mycelia [41], as well as glucans and ergosterol content in Pleurotus [42]. In an earlier study, it was also used to show how physical harm had an effect on tissue structure and the aging process [43]. The most intriguing application of this technique is currently the degradation processes of various agricultural waste for mushroom cultivation [44,45].

To this aim, G. lucidum, L. edodes, and P. cornucopiae were grown on HS substrates in order to evaluate their potential as alternative growth substrates. In order to accomplish this objective, mycelia growth rate and biological efficiency were studied. Additionally, micro ATR-FTIR was applied to explore the substrate breakdown and the composition of the fruiting bodies.

\section{Materials and Methods}

\subsection{Substrates}

The hazelnut shells were provided by an organic farm located in Carrù (Cuneo, Piedmont, Italy). Wheat straw (WS) and Fagus sp. L. chips (Beech Chips, BC) were kindly provided by the Cadriano farm of the University of Bologna. Wheat straw and BC were crushed into fragments smaller than $0.5 \mathrm{~cm}$; HS was crushed with a cutting mill (Retsch, SM 100) and autoclaved at $121 \pm 1{ }^{\circ} \mathrm{C}$ for $60 \mathrm{~min}$ to prevent any contamination during storage. The dried raw materials were stored at $22 \pm 1^{\circ} \mathrm{C}$. 


\subsection{Mushrooms Cultures and Mycelial Growth Rate Evaluation}

Experimental trials were carried out by using three species of Basidiomycetes mushrooms: G. lucidum, L. edodes, and P. cornucopiae.

Ganoderma lucidum (strain Glu16) and P. cornucopiae (strain Pco3) were isolated from fruiting bodies collected in the wild; L. edodes strain (LEd5) was brought by the Fungal Institute of Jinxiang (Shandong province, China).

The mycelial pure cultures were stored in the Mycological and Applied Botany Laboratory of the Department of Agricultural and Food Sciences (DISTAL) at the University of Bologna (Bologna, Italy). The isolates were kept at $22 \pm 1{ }^{\circ} \mathrm{C}$ in darkness on Potato Dextrose Agar (PDA, Difco) half strength and subcultured every two months.

For mycelial growth area evaluation, plugs of $10 \mathrm{~mm}$ diameter were taken by 15-dayold colonies of each species and inoculated in the center of $9 \mathrm{~cm}$ sterilized Petri dish filled with $30 \mathrm{~g}$ of three different substrates previously soaked for $24 \mathrm{~h}$ with distilled water and brought to 70\% humidity: Hazelnut Shell (HS); Wheat Straw 50\%-Hazelnut Shell 50\% (WS 50\%-HS 50\%) and Wheat Straw (WS) as control. Five replicates were made for each combination of species and substrate. All plates were incubated at $22 \pm 1{ }^{\circ} \mathrm{C}$ in darkness. The fungal growth was assessed by measuring the diameter of the colony along two preset diametrical lines every day.

The area $\left(\mathrm{cm}^{2}\right)$ covered daily by the mycelium was calculated assuming an elliptical shape as reported by [46] using the following formula:

$$
A=\pi \times R_{1} \times R_{2}
$$

where $A$ is the fungal colony area $\left(\mathrm{cm}^{2}\right)$ and $R_{1}$ and $R_{2}$ are the two perpendicular radii, respectively.

The area growth rate of the mycelium $(A G R)$ was calculated with the formula of Sinclair and Cantero [47] modified as follows:

$$
A G R=\frac{A_{f}-A_{i}}{T_{f}-T_{i}}
$$

where $A G R$ is the growth rate $\left(\mathrm{cm}^{2}\right.$ day $\left.^{-1}\right) ; A_{f}$ is the final growth area $\left(\mathrm{cm}^{2}\right) ; A_{i}$ is the initial growth area $\left(\mathrm{cm}^{2}\right)$ and $T_{f}$ is the final growth time (days); $T_{i}$ is the initial growth time (days).

\subsection{Mushrooms Cultivation Trials}

Spawn production occurs in inoculated glass tubes containing $30 \mathrm{~g}$ of sorghum kernels and distilled water in a 1:2 $(v / v)$ ratio, previously sterilized at $121 \pm 1{ }^{\circ} \mathrm{C}$ for $20 \mathrm{~min}$, with two 15-day-old mycelial plugs of $1 \mathrm{~cm}$ diameter. Five replicates were prepared for each species-substrate combination. The tubes were incubated in the dark at $22 \pm 1{ }^{\circ} \mathrm{C}$ for 30 days with the aim to obtain the complete colonization of the kernels.

Two different HS-based substrates were used as reported in Table 1; a substrate composed of wheat straw $50 \%$ and Beech Chips $50 \%$ was used as a control. Homogeneous substrate mixtures were prepared by mixing component materials based on their dry weight $(w / w)$.

Table 1. Composition and ratios of the substrates used in cultivation trials.

\begin{tabular}{ccc}
\hline Substrates and Mixing Ratio & Code & Average Dry Weight (g) \\
\hline Wheat Straw 50\%-Beech Chips 50\% (control) & WS-BC & 400 \\
Wheat Straw 50\%-Hazelnut Shells 50\% & WS-HS & 900 \\
Hazelnut Shells 100\% & HS & 1500 \\
\hline
\end{tabular}

The substrates were inserted into autoclavable polypropylene (PP) transparent bags $(20 \times 30 \mathrm{~cm})$. Dried mixed substrates were moistened with $1 \mathrm{~L}$ (per bag) of distilled water for $24 \mathrm{~h}$ and the excess of water was removed by squeezing the bags. 
Bags were closed with a PP plastic cap with a filter, autoclaved at $121 \pm 1{ }^{\circ} \mathrm{C}$ for $60 \mathrm{~min}$; inoculated with grain spawn by opening the bag, inserting the inoculum inside it (1 tube per bag), mixing the inoculum with the substrate, and incubated in the darkness at $22 \pm 1{ }^{\circ} \mathrm{C}$ until the complete colonization of the substrate. For each species-substrate combination, five bags were prepared.

After 1 or 2 months of mycelial growth, depending on the substrate (one month on WS and WS-BC and around 2 month on HS), bags were moved to a climatic chamber with different climatic conditions (Table 2) according to their biological needs [48].

Table 2. Cultivation parameters used in the trials.

\begin{tabular}{cccc}
\hline & \multicolumn{3}{c}{ Species } \\
\hline & Ganoderma lucidum & Lentinula edodes & Pleurotus cornucopiae \\
\hline Temperature $\left({ }^{\circ} \mathrm{C}\right)$ & $22-30$ & $10-20$ & $18-25$ \\
Light intensity $(\mathrm{Lux})$ & $500-1000$ & $500-1000$ & $500-1000$ \\
Relative Humidity $(\%)$ & $85-95$ & $60-95$ & $80-95$ \\
\hline
\end{tabular}

Lentinula edodes fruiting body were collected only when the cap radius reached $5 \mathrm{~cm}$ in diameter [49]. Ganoderma lucidum and P. cornucopiae were collected when the cap was completely developed. The duration of the harvest periods, starting from the appearance of the first primordia, was two months for L. edodes and P. cornucopiae and 3 months for G. lucidum. All fruiting bodies were freshly weighted, dried in a stove at $40{ }^{\circ} \mathrm{C}$ for $24 \mathrm{~h}$, and their dried weight was recorded. Biological efficiency was calculated according to Chang et al., 1981 [50].

\subsection{Micro ATR-FTIR Spectroscopy Analysis}

A Bruker Tensor FT-IR instrument (Bruker Optics, Ettlingen, Germany) equipped with an accessory for analysis in ATR was used. The sampling device contained a microdiamond crystal, single reflection with an angle of incidence of $45^{\circ}$ (Specac Quest ATR, Specac Ltd., Orpington, Kent, UK). Spectra were recorded from 4000 to $400 \mathrm{~cm}^{-1}$, with a spectral resolution of $4 \mathrm{~cm}^{-1}$ and 64 scans. Background spectra were also taken against air under the same conditions before each sample.

The substrates from in vitro test were analyzed after 30 days of mycelial growth, as previously described by Fornito et al., 2020 [44]. Parts of dried fruiting bodies (cap, hymenophore, and stipe) grown on the HS and WS-BC of each species were placed on the diamond crystal, and pressure was applied with a compression clamp. The resulting spectra of each type of sample were averaged. Isopropyl alcohol was used to clean the diamond crystal before each recording.

\subsection{Statistical Analyses}

Statistical analyses were performed using the RStudio [51] graphical interface for the R software environment v.4.0.2 (R Foundation, Vienna, Austria) with the packages agricolae, ggplot2, Hmisc, and mice. The analysis of variance (ANOVA) and Kruskal-Wallis test were used to determine the significant difference of AGR, Fruiting body production (FBP, expressed as dry weight of mushrooms collected during the harvesting period), and biological efficiency among different substrates. Tukey post hoc test $(p \leq 0.05)$ was used to compare the means.

\section{Results}

\subsection{In Vitro Mycelial Growth and ATR-FTIR of Substrates}

Figure 1 shows the in vitro mycelial growth of the tested fungi in the three different substrates. Only P. cornucopiae showed a significantly higher mycelial growth rate on WS (Figure 1e,f). The growth of G. lucidum, L. edodes, and P. cornucopiae was significantly lower on HS with respect to the other substrates (Figure 1a,c,e). Statistical differences were found 
between the area growth rate of G. lucidum and L. edodes grown on HS respect to WS and WS-HS (Figure 1b,d).
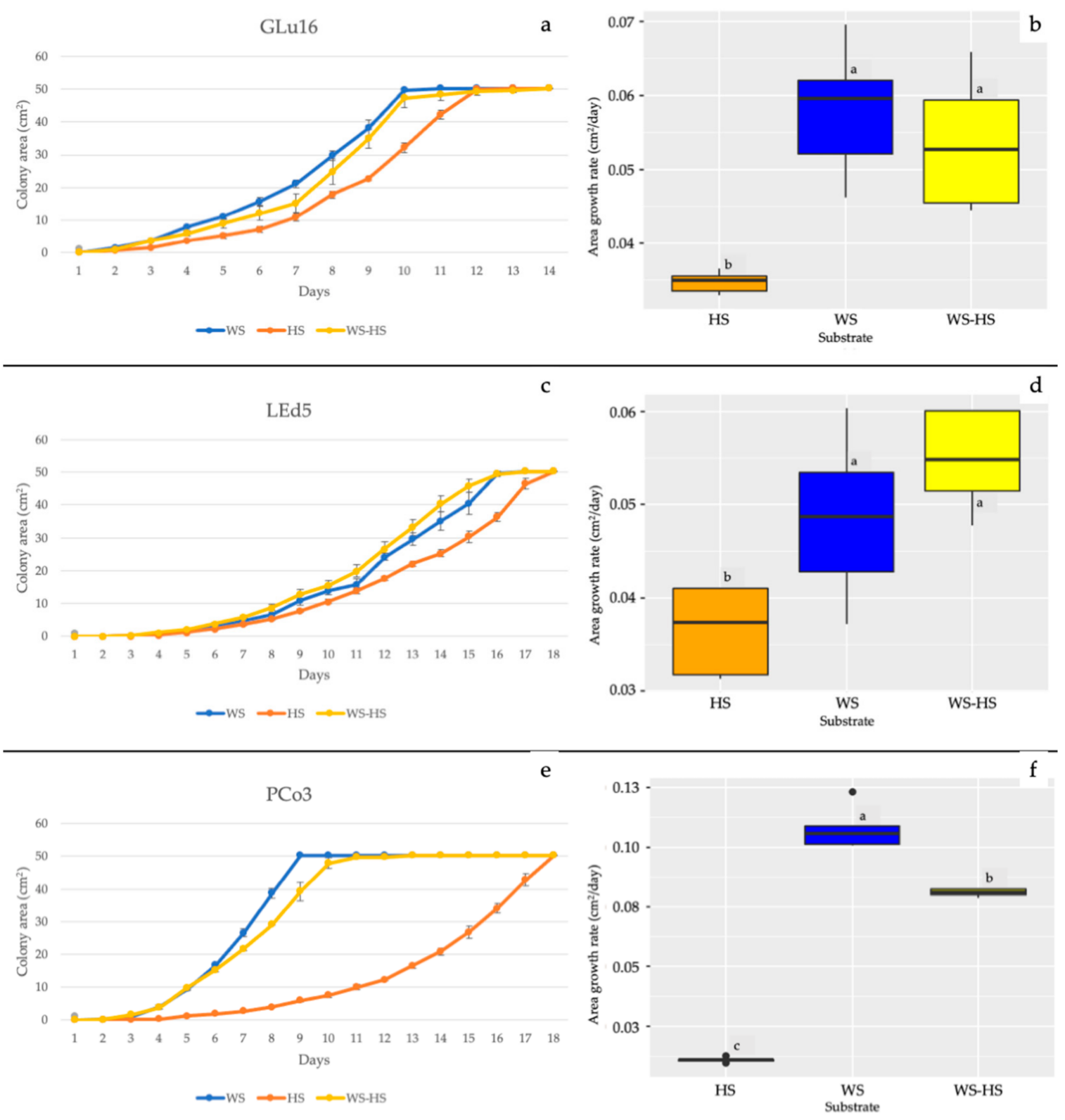

Figure 1. Growth and AGR of (a,b) Ganoderma lucidum, (c,d) Lentinula edodes, and (e,f) Pleurotus cornucopiae in Petri dishes on WS (blue), HS (orange), and WS-HS (yellow). Different letters indicate significant differences at $p \leq 0.05$.

In the fingerprint region (1800-600 $\mathrm{cm}^{-1}$ ) of the substrate spectra, WS and HS, and after 30 days of mycelial growth, consistent structural variation for both substrates were found for G. lucidum, L. edodes, and P. cornucopiae (Figure 2a,b). In the WS spectrum (black line) (Figure 2a), the bands at $1735 \mathrm{~cm}^{-1}$, due to unconjugated $\mathrm{C}=\mathrm{O}$, and at $1460 \mathrm{~cm}^{-1}(\mathrm{C}-\mathrm{H}$ deformation), correspond to those of xylan (hemicellulose) or the heterocyclic cellulosic rings [52]. The peak at $1623 \mathrm{~cm}^{-1}$ may be assigned to carboxylates in aromatic rings. The shoulder at $1517 \mathrm{~cm}^{-1}$ was attributed to the aromatic skeletal vibrations $(C=C)$ and aromatic breathing in lignin, respectively [53-55]. The bands at $1423 \mathrm{~cm}^{-1}$ and $1322 \mathrm{~cm}^{-1}$ were assigned to $\mathrm{C}-\mathrm{H}_{2}$ bending at C- 6 of the crystalline cellulose [56], and that at $1370 \mathrm{~cm}^{-1}$ was due to $\mathrm{CH}_{2}$ bending vibrations in cellulose and hemicellulose. The region between 1100 and $950 \mathrm{~cm}^{-1}$ corresponded to that of cellulose and hemicelluloses. The most intense 
bands centered at $1031 \mathrm{~cm}^{-1}$ were assigned to the $\mathrm{C}-\mathrm{O}-\mathrm{C}$ stretching of primary alcohol in cellulose and hemicellulose [57]. The weak shoulder at $898 \mathrm{~cm}^{-1}$ was associated with C1-O-C $\beta-(1-4)$-glycosidic linkage in cellulose. The other bands at approximately $700 \mathrm{~cm}^{-1}$ and $600 \mathrm{~cm}^{-1}$ were assigned to the $\mathrm{C}-\mathrm{OH}$ bending $[58,59]$.
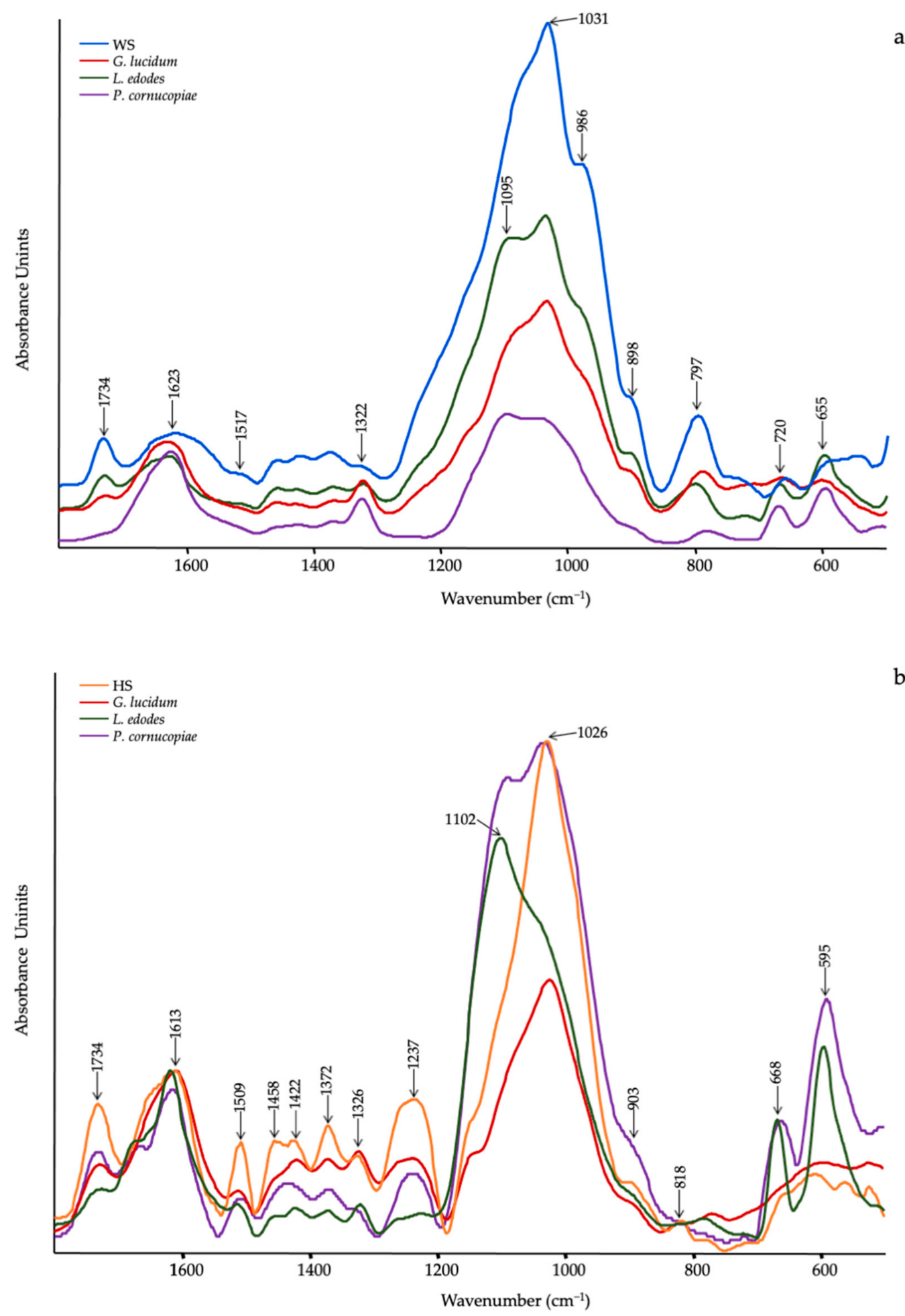

Figure 2. ATR-FTIR spectra of (a) WS (blue line) and (b) HS (orange line) after $30 \mathrm{~d}$ of mycelial growth of G. lucidum (red line), L. edodes (green line) and Pleurotus cornucopiae (purple line). 
After 30 days of mycelial growth, a considerable structural modification was observed. In particular, the progressive decrease of xylan in hemicellulose $\left(1735 \mathrm{~cm}^{-1}\right.$ and $\left.1460 \mathrm{~cm}^{-1}\right)$ in L. edodes and G. lucidum and the total disappearing in P. cornucopiae was observed in the spectra (Figure 2a).

Lignin decay may be ascertained in the decreased intensity of absorption bands at around $1623 \mathrm{~cm}^{-1}$, appearing more significant in $P$. cornucopiae. Conversely, the band at $1322 \mathrm{~cm}^{-1}$ (Figure 2a) increased in G. lucidum and P. cornucopiae. More significant variations were also observed in the glycosidic $\mathrm{C}-\mathrm{O}-\mathrm{C}$ band $\left(1100-950 \mathrm{~cm}^{-1}\right)$, showing an alteration of the linkage $\mathrm{C} 1-\mathrm{O}-\mathrm{C} \beta-(1-4)$-sugar of the polymeric cellulose in the following order: P. cornucopiae $>$ G. lucidum $>$ L. edodes, probably as a result of cellulose degradation processes. As shown in Figure $2 b$, the HS spectrum (blue line) displayed a number of adsorption peaks, indicating the complex nature of the material examined [60]. More precisely, the peak centered at $1734 \mathrm{~cm}^{-1}$ could be ascribed to acetyl and uronic ester groups in hemicellulose and $\rho$-coumaric acids in lignin [40]. The bands at $1613 \mathrm{~cm}^{-1}$ and $1509 \mathrm{~cm}^{-1}$ corresponded to the aromatic skeletal vibration in lignin [52] as well as the bands at $1458 \mathrm{~cm}^{-1}$. In addition, the bands at $1422 \mathrm{~cm}^{-1}$ were derived from C-H bending in lignin. The cellulose and hemicellulose bands appeared at $1372 \mathrm{~cm}^{-1}$ and 1326 $\mathrm{cm}^{-1}$ ( $\mathrm{C}-\mathrm{H}$ bending). Nevertheless, the last band also may be assigned to $\mathrm{C}-\mathrm{O}$ vibration in syringyl derivatives as well as the band at approximately $1237 \mathrm{~cm}^{-1}$, due to syringyl ring and $\mathrm{C}-\mathrm{O}$ stretching in lignin and xylan [60]. The most intense region from 1100 to $900 \mathrm{~cm}^{-1}$ was attributed to $\mathrm{C}-\mathrm{O}$ and $\mathrm{C}-\mathrm{O}-\mathrm{C}$ stretching in cellulose and hemicellulose. Spectra after mycelia growth showed a progressive reduction in the relative intensity of the aromatic rings $\left(1509 \mathrm{~cm}^{-1}, 1326 \mathrm{~cm}^{-1}\right.$, and $\left.1237 \mathrm{~cm}^{-1}\right)$ in this order: L. edodes > G. lucidum $>$ P. cornucopiae. Likewise, the gradual decrease in the peak at $1734 \mathrm{~cm}^{-1}$ might be related to the presence of $\rho$-coumaric acids from the lignin rather than the hemicellulose. In the region corresponding to cellulose and hemicelluloses (1100 to $\left.900 \mathrm{~cm}^{-1}\right)$, a significant increase in $\mathrm{C}-\mathrm{O}\left(1102 \mathrm{~cm}^{-1}\right)$ group in P. cornucopiae and L. edodes was detected. On the contrary, the $\mathrm{C}-\mathrm{O}-\mathrm{C}$ group decreased in G. lucidum and L. edodes (Figure 2b).

\subsection{Fruiting Body Production}

In Figure 3, the FBP and the biological efficiency of all the tested fungi in different substrates are reported. The FBP of L. edodes was significantly higher on HS than on the other tested substrates (Figure 3c). The P. cornucopiae FBP on HS was significantly higher than on WS-BC but had similar production as on WS-HS (Figure 3e). In contrast, the FBP of G. lucidum was significantly lower in HS than WS-BC but similar to FBP on WSHS (Figure 3a). Regarding the biological efficiency, all the tested fungi showed a higher biological efficiency on WS-BC with respect to the other substrates (Figure 3b,d,f).

\subsection{Qualitative Evaluation of Mushrooms by ATR-FTIR}

The spectra of the fruiting bodies of G. lucidum, L. edodes, and P. cornucopiae produced on different growing media (HS and WS-BC) are shown in Figure 4.

As no spectral difference from $1800 \mathrm{~cm}^{-1}$ to $800 \mathrm{~cm}^{-1}$ was detected between the cap, the gills, and the stipe in either L. edodes or P. cornucopiae, the spectra were averaged (Figure 4a,b). Conversely, in the G. lucidum spectra, a significant spectral variation was observed between the cap and the hymenophore (Figure $4 \mathrm{c}, \mathrm{d}$ ). The characteristic bands of the main functional groups are listed in Table 3. 

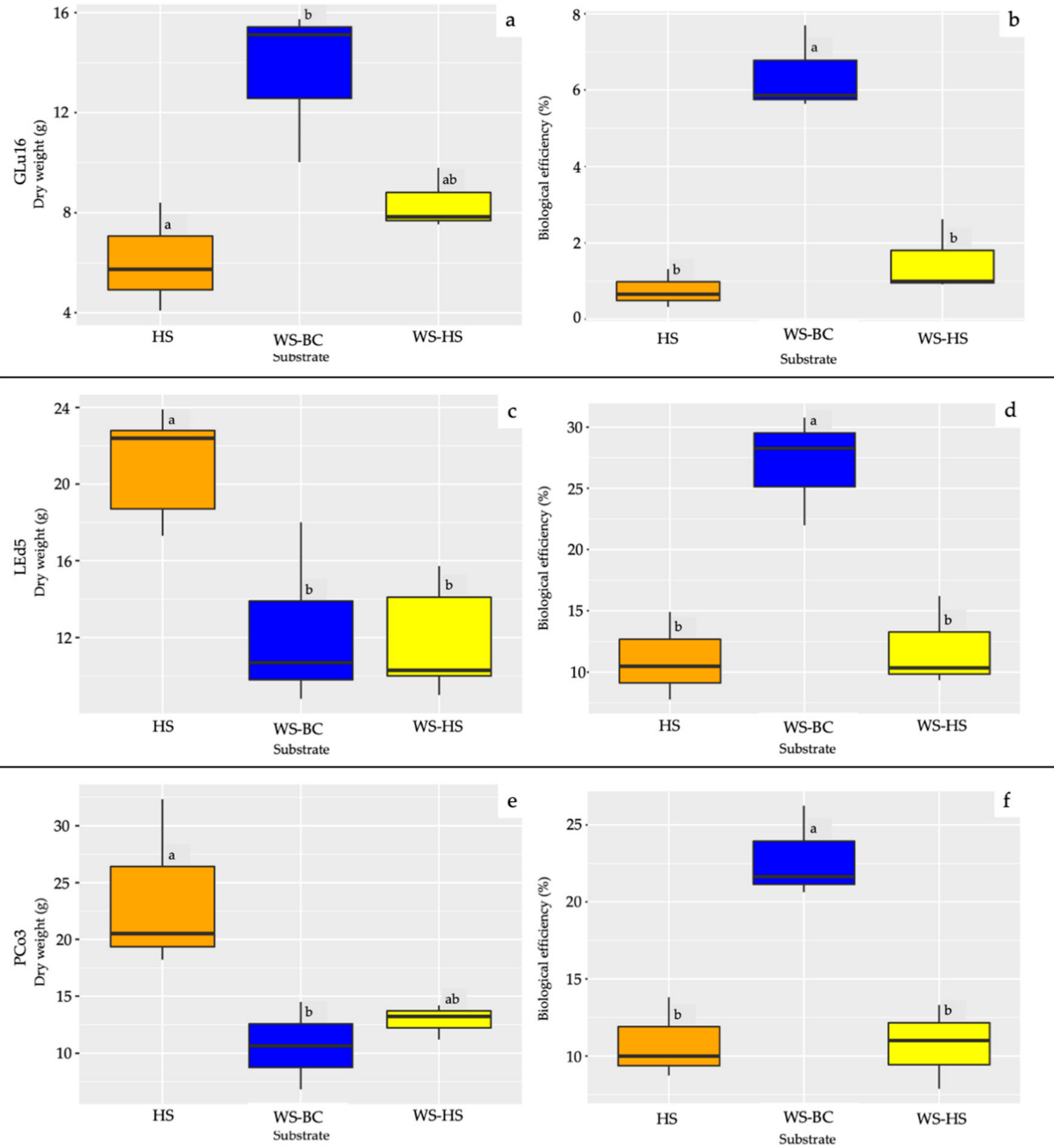

Figure 3. FBP and biological efficiency of $(\mathbf{a}, \mathbf{b})$ Ganoderma lucidum; $(\mathbf{c}, \mathbf{d})$ Lentinula edodes, and (e,f) Pleurotus cornucopiae grown on HS (orange), WS-BC (blue), and WS-HS (yellow). Different letters indicate significant differences at $p \leq 0.05$. 


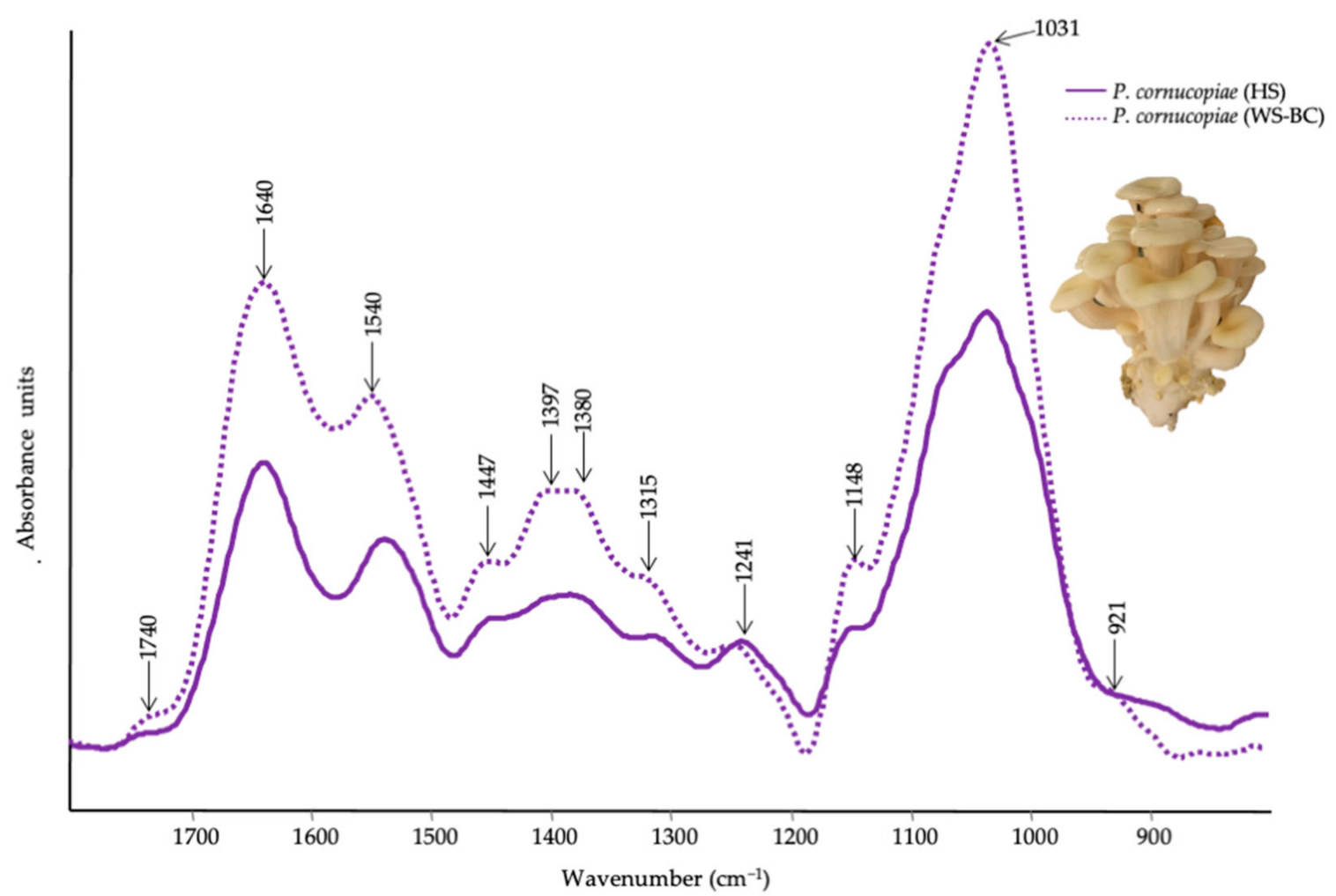

b

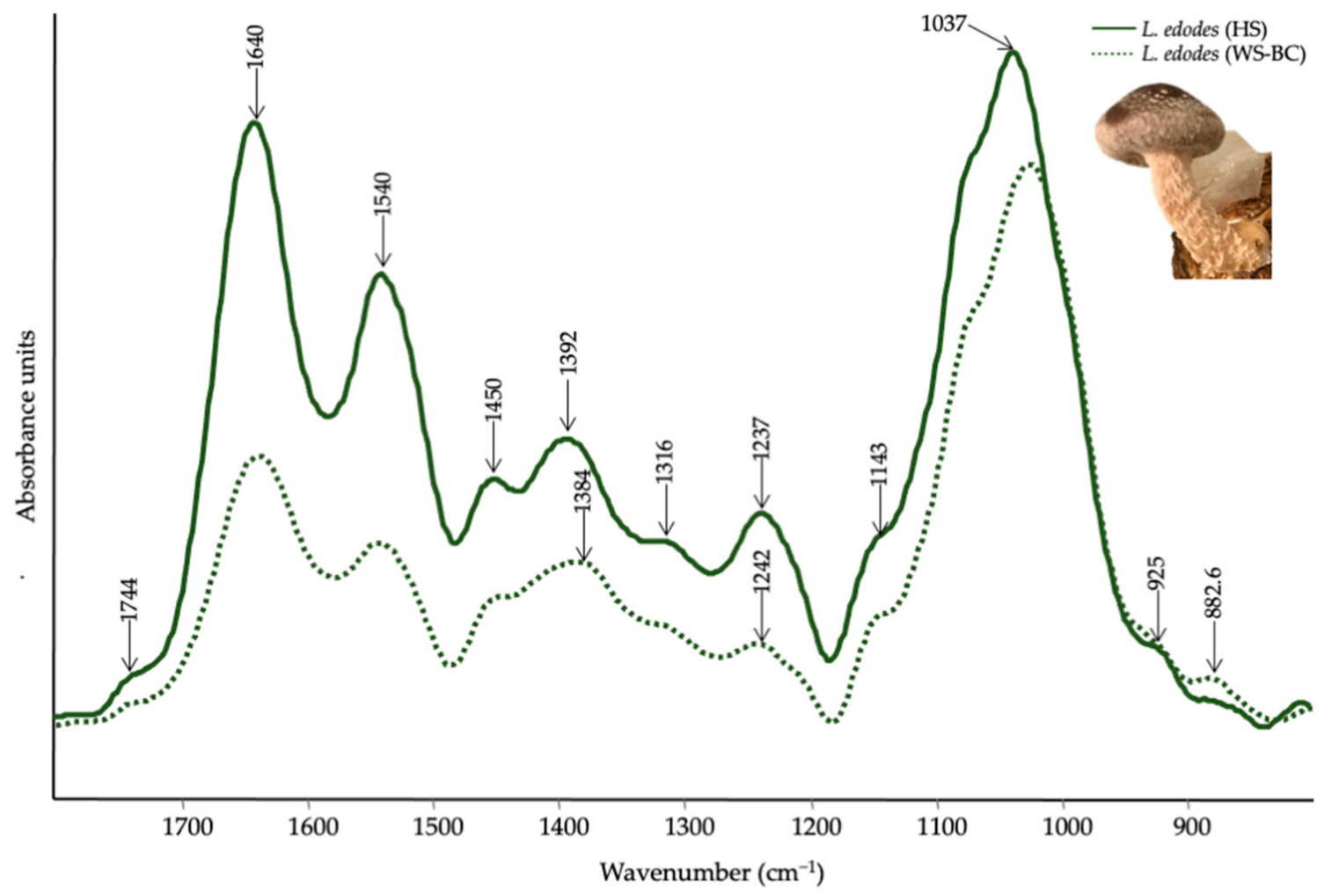

Figure 4. Cont. 

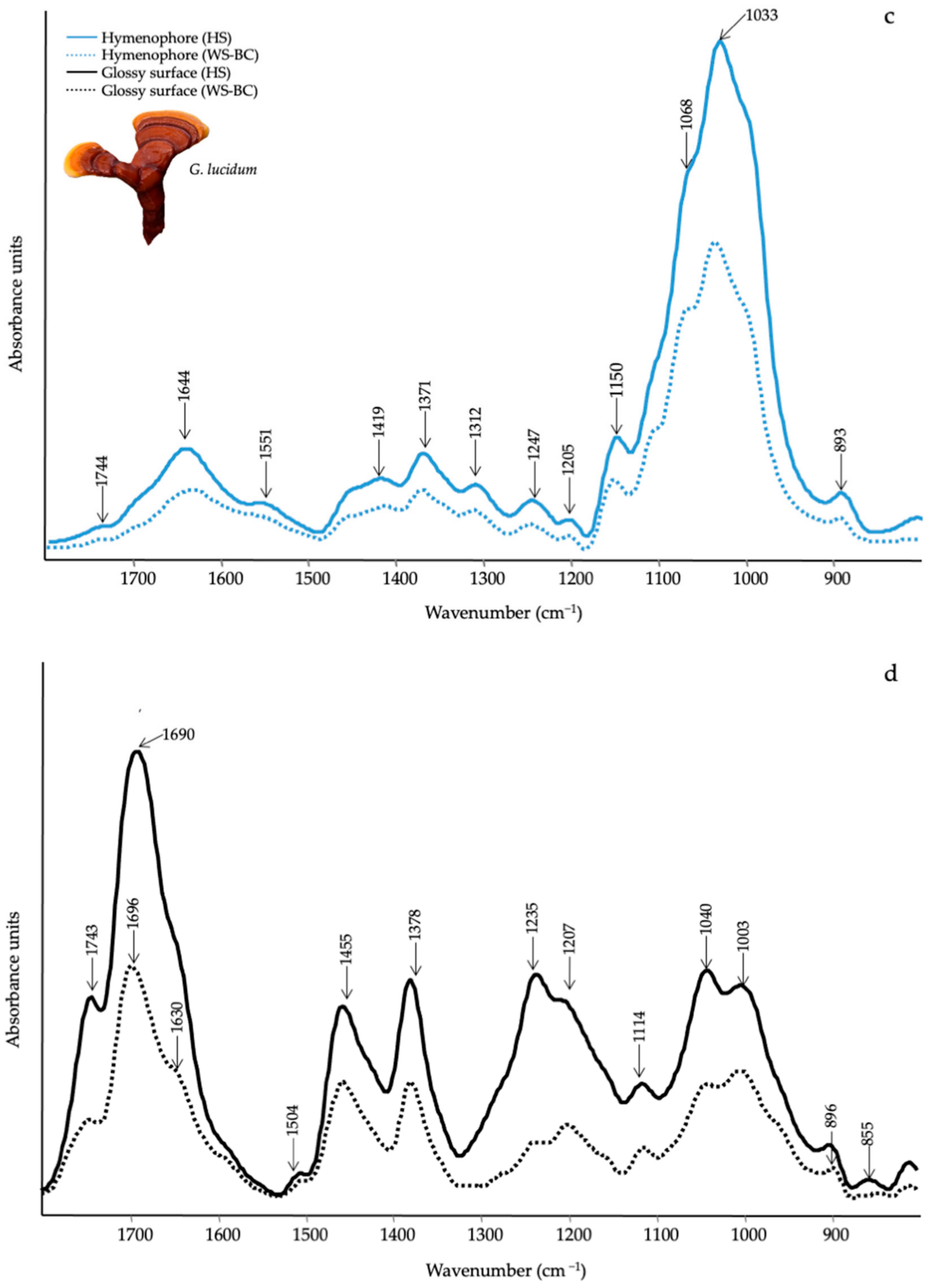

Figure 4. ATR-FTIR spectra of the fruiting bodies of (a) P. cornucopiae cultivated on WS-BC (dotted purple line) and HS (solid purple line); (b) L. edodes cultivated on WS-BC (dotted green line) and HS (solid green line); (c) G. lucidum hymenophore on WS-BC (dotted cyan line) and HS (solid cyan line); (d) G. lucidum glossy surface on WS-BC (dotted black line) and HS (solid black line). 
Table 3. Attributions of the main characteristic FT-IR bands in the spectra of G. lucidum, L. edodes and P. cornucopiae fruiting bodies according to the literature.

\begin{tabular}{ccc}
\hline Wavenumber $\left(\mathbf{c m}^{-\mathbf{1}} \mathbf{)}\right.$ & Functional Groups Attributions & Reference \\
\hline $1745-1738$ & $\mathrm{C}=$ O stretching of lipids & {$[61]$} \\
$1696-1690$ & CHO stretching in aromatic & {$[62]$} \\
$1640-1638$ & Amide I, water & {$[61]$} \\
$1540-1548$ & Amide II & {$[61]$} \\
1507 & Aromatic ring & {$[62]$} \\
1455 & $\mathrm{CH}_{2}$ bending in polysaccharides & {$[39]$} \\
$1400-1378$ & $\mathrm{C}-\mathrm{H}$ in-plane bending vibration & {$[63]$} \\
$1245-1235$ & Amide III and C-O stretching & {$[40]$} \\
$1150-1157$ & $\mathrm{C}-\mathrm{O}-\mathrm{C}$ asymmetric stretching of glycosidic & {$[43]$} \\
$1040-1025$ & linkage & {$[43]$} \\
$930-882$ & stretching vibration of C-O-C group & {$[64]$} \\
$807-796$ & Glucan band $\beta$ anomer; C-H deformation & {$[64]$} \\
\hline
\end{tabular}

In the spectra of P. cornucopiae and L. edodes (Figure $4 \mathrm{a}, \mathrm{b}$ ) are well identifiable the Amide I $\left(\sim 1640 \mathrm{~cm}^{-1}\right)$, Amide II $\left(\sim 1540 \mathrm{~cm}^{-1}\right)$ and Amide III $\left(\sim 1240 \mathrm{~cm}^{-1}\right)$ bands of proteins [61]. Another characteristic is valuable in the region of polysaccharides vibrations between 1150-796 $\mathrm{cm}^{-1}$ (Table 3). More specifically, the bands at about $807 \mathrm{~cm}^{-1}$ and $930 \mathrm{~cm}^{-1}$ are corroborating for mannan [ $\alpha$ (1-6) linked backbone with $\alpha(1-3)$ and $\alpha(1-2)$ linked branches] a type of glucan that is one component of fungal cell walls and chitin $(\mathrm{N}$ acetylglucosamine based polymer), respectively [64]. A weak shoulder at around $1740 \mathrm{~cm}^{-1}$ indicated the presence of cell membrane phospholipids [61]. Pleurotus cornucopiae grown on WS-BC and HS (Figure 4a) showed a similar spectral profile, although an increase in the relative intensity of the bands was seen in presence of WS-BC and more specifically, in the polysaccharide region. At the opposite, the spectra of L. edodes grown on HS consistently showed an increase in the relative intensity of all bands as compared to the WS-BC substrate (Figure $4 b$ ). However, no relevant structural variation was observed.

Referring to the spectra of G. lucidum grown on HS and WS-BC, a different spectral profile was detected both in the external and inner parts of the fruiting body and in the different substrate (Figure $4 \mathrm{c}, \mathrm{d}$ ). The glossy surface part of both cap and stipe were characterized by esterified carboxyl groups in lipids at $1745 \mathrm{~cm}^{-1}$ and $1235 \mathrm{~cm}^{-1}$, respectively. These bands may also be coupled to vibrations at $1455 \mathrm{~cm}^{-1}$ and $1378 \mathrm{~cm}^{-1}$ in C-H bending of aliphatic compounds. The band at $1690 \mathrm{~cm}^{-1}, 1630 \mathrm{~cm}^{-1}$, and $1504 \mathrm{~cm}^{-1}$ were due to aromatic rings vibrations [62]. The region from 1100 to $896 \mathrm{~cm}^{-1}$ belonged to the vibration of $\mathrm{C}-\mathrm{C}-\mathrm{O}$ or $\mathrm{C}-\mathrm{C}-\mathrm{OH}$ in polysaccharides (Table 3 ). In the inner part of the fruiting body and hymenophore, the lipid functional groups $\left(1744 \mathrm{~cm}^{-1}, 1450 \mathrm{~cm}^{-1}, 1371 \mathrm{~cm}^{-1}\right.$ and $1247 \mathrm{~cm}^{-1}$ ) become weaker (Figure 4c) than those observed in the surface. Instead, the bands of amide I, $\left(1644 \mathrm{~cm}^{-1}\right)$ and amide II $\left(1551 \mathrm{~cm}^{-1}\right)$ were visible. The spectra were also dominated by the intense bands assigned to polysaccharides from 1150 to $893 \mathrm{~cm}^{-1}$. By comparing the spectra of G. lucidum grown on HS and WS-BC, the main variations occurred in the polysaccharide region, which appeared more intense in HS than in WS-BC.

\section{Discussion}

The circular economy in the agro-wastes management sector requires reusing these materials as a feedstock in a variety of production cycles. In this context, the high production of hazelnuts has led to a significant accumulation of wood residues frequently involved in manufacturing processes, potentially impacting the environment.

In this work, we explored the potential of HS as a growing substrate for the cultivation of edible and medicinal mushrooms.

Preliminary results in Petri dishes indicated that all the three tested species were able to grow on HS (Figure 1), which was never used for mushroom cultivation. 
It is well known that the $\mathrm{C} / \mathrm{N}$ ratio is one of the most important parameters for mushroom growth and cultivation [65]. The $\mathrm{C} / \mathrm{N}$ ratio of hazelnut shells ranged from 43.4 to 58 [66-68]; this C/N ratio is optimal for L. edodes and P. cornucopiae and sub-optimal for G. lucidum. In fact, the optimal C/N ratio for L. edodes and P. cornucopiae ranges from 30-35 and 45-55, respectively, whereas G. lucidum development is favored by $\mathrm{C} / \mathrm{N}$ ratios between 70 and $80[48,68]$.

All the tested species are considered white-rot fungi naturally found on hardwood [69]. However, G. lucidum, L. edodes, and P. cornucopiae showed a different behavior on the tested substrates. Pleurotus cornucopiae grow better on WS and WS-HS with respect to HS (Figure 1e,f), this different behavior could be due to the different lignin percentage in HS (ranging from 40 to 50\%) [5-7] with respect to WS (15\%) [70,71] and the greater presence of soluble sugars and nutrients present in WS. In fact, P. cornucopiae on WS and WS-HS rapidly covered the surface of the plate and then degraded its cellulose and available hemicellulose. In contrast, in HS substrate, lesser soluble nutrients were released, and lesser cellulose and hemicellulose were available without previous degradation of lignin. Moreover, P. cornucopiae is typically found on poplar wood which contains a percentage of lignin ranging from 16 to $21 \%$ [72]. On the other hand, G. lucidum and L. edodes are commonly found on oaks and on chestnut trees, whose lignin content ranging from $18-30 \%$ in oak wood to $26 \%$ in chestnut wood $[73,74]$.

The efficiency of mycelial growth on different substrates may be related to the structural modification detected in the spectra (Figure 2a,b). Since the lignocellulose is the major component of any substrate, the changes observed in the spectra presumed a synergistic action of several enzymes $[68,75]$. As expected, the mycelial growth of $P$. cornucopiae in WS$\mathrm{BC}$ resulted in a change in the acetyl and uronic ester groups of hemicellulose $\left(1734 \mathrm{~cm}^{-1}\right)$ and in those bound to the $\mathrm{C} 1-\mathrm{O}-\mathrm{C} \beta-(1-4)$-sugar bond of cellulose. Based on these structural changes, we can surmise that enzymatic hydrolysis led to a total degradation of $\beta-(1,4)$ glycosidic bonds with the missing band at $898 \mathrm{~cm}^{-1}$ and the production of new simple molecules, most likely as sugar acids (Figure 2a). Substrate degradation activity by G. lucidum and L. edodes did not lead to significant structural changes in WS-BC, even though in G. lucidum is visible light degradative activity of acetyl and uronic ester groups of hemicellulose $\left(1734 \mathrm{~cm}^{-1}\right)$.

As previously reported, the higher mycelia growth capacity of G. lucidum and L. edodes on HS could be related with the high lignin, cellulose, and hemicellulose contents. Specifically, G. lucidum caused a modification of the HS substrate with reduction of the acetyl and uronic ester groups of hemicellulose $\left(1734 \mathrm{~cm}^{-1}\right)$ and of those linked to the $\mathrm{C} 1-\mathrm{O}-\mathrm{C} \beta-(1-4)$-sugar bond of cellulose. In addition, the typical lignin aromatic ring $\left(1509 \mathrm{~cm}^{-1}\right)$ showed consistent degradation that, coupled with the gradual decrease of the peak at $1734 \mathrm{~cm}^{-1}$ related to $\rho$-coumaric acids rather than to hemicellulose, suggests that lignin degradation is the first level of lignocellulose degradation in order that cellulose and hemicellulose accessibility is more feasible [76]. With L. edodes and P. cornucopiae, the alterations were mainly related to the region of cellulose and hemicelluloses (1100 to 900 $\mathrm{cm}^{-1}$ ). The increase in these bands may indicate that a variety of hydrolytic enzymes could be released during fungal attacks specifically to modify and break the bonds of the lignin and hemicellulose; the chemical changes in these compounds signal that the fungus could take them as carbon sources.

After in vitro preliminary tests, cultivation trials conducted on G. lucidum, L. edodes, and P. cornucopiae showed a biological efficiency on HS $(0.8,11.0$, and $10.8 \%$, respectively) lower than those obtained on WS-BC $(6.4,21.9$, and $22.9 \%$, respectively), but the biological efficiency on WS-BC are in line with those previously obtained by other authors [77-79]. The lower biological efficiency on HS could be attributed to the higher dry weight of the substrate used to fill each bag. Lentinula edodes and P. cornucopiae showed a good FBP, proving capable of exploiting HS-based substrates, although the growth of $P$. cornucopiae in vitro was slower than WS and WS-HS. In contrast, G. lucidum had a lower FBP on HS despite rapid development in vitro. The mycelial colonization and the fruiting body 
production could not be strictly correlated as in not ideal substrates; several fungi show a faster colony expansion for a foraging strategy [80].

A spectroscopic comparison of P. cornucopiae fruiting bodies grown on WS-BC displayed a higher content in polysaccharide than those on HS (Figure 4a). The higher biosynthesis of polysaccharides in P. cornucopiae is strongly influenced by the chemical composition of the substrates, and in particular, by cellulose and hemicellulose availability as also claimed by Bekiaris, 2020 [42]. Conversely, in L. edodes grown on HS, polysaccharides increased, chitin in particular, confirming the role of the substrate composition. It is known that $L$. edodes grown on a wood log have a greater economic value than those grown on WS for their better quality [81]. Our preliminary sensory data showed that the fruiting bodies of L. edodes grown on HS have a better texture, probably due to the higher chitin content [82], aroma, and color than those grown on WS-BC (data not shown). These differences could be due to the high lignin content present in HS, which could provide a fruiting body qualitatively similar to those obtained on wood logs. This result also suggests that a high chitin and polysaccharide content in the L. edodes fruiting bodies could be an indicator of the quality of its fruiting bodies. On the other hand, differences in the chemical composition of the medicinal mushroom G. lucidum were found both on the glossy surface and in the inner part of the fruiting bodies grown on WS-BC and HS. It is confirmed that the HS substrate led to the enhancement of polysaccharides with respect to those grown on WS-BC. Polysaccharides are the most biologically active substances in G. lucidum endowed with antitumor, antiviral, antioxidant, and immunomodulatory activities and for medicinal uses of Ganoderma spp. the Chinese Pharmacopoeia has established a minimum content of polysaccharides in the dry fruiting body [35].

\section{Conclusions}

The high demand for hazelnuts and their consequent use in the food industry leads to an accumulation of woody biomass consisting of HS. The valorization of HS as a substrate for mushroom cultivation is an environmentally friendly alternative to the conventional utilization of such agricultural waste by-products.

The results obtained in this study support the economic applicability of HS as a substrate or supplement for mushroom cultivation according to circular economy criteria and in order to obtain high-quality food. The high lignin content of HS makes it an appropriate substrate for mushroom cultivation, resulting in greater optimization of this agricultural waste by-product and, consequently, more profit for mushroom farms. In addition, at the end of the fungal growth cycle, the spent mushroom substrate after lignocellulosic degradation may also be used to improve soil fertility by supplying beneficial nutrients for crops.

Author Contributions: Conceptualization, F.P. and P.L.; methodology, O.F.; validation, P.L. and F.M.; formal analysis, P.L. and F.M.; investigation, F.P., P.L. and F.M.; resources, A.Z. and O.F.; data curation, P.L. and F.M.; writing—original draft preparation, F.P.; writing—review and editing, A.Z. and O.F.; visualization, F.P.; supervision, A.Z. and O.F. All authors have read and agreed to the published version of the manuscript.

Funding: This research received no external funding.

Institutional Review Board Statement: Not applicable.

Informed Consent Statement: Not applicable.

Data Availability Statement: The data presented in this study are available on request from the corresponding author.

Conflicts of Interest: The authors declare no conflict of interest. 


\section{References}

1. Food and Agricultural Organization of the United Nations. FAOSTAT. Available online: https://www.fao.org/faostat/en/\#data/ QCL (accessed on 15 December 2021).

2. Król, K.; Gantner, M. Morphological traits and chemical composition of hazelnut from different geographical origins: A review. Agriculture 2020, 10, 375. [CrossRef]

3. Silvestri, C.; Bacchetta, L.; Bellincontro, A.; Cristofori, V. Advances in cultivar choice, hazelnut orchard management, and nut storage to enhance product quality and safety: An overview. J. Sci. Food Agric. 2021, 101, 27-43. [CrossRef]

4. Król, K.; Gantner, M.; Piotrowska, A. The quality characteristic and fatty acid profile of cold-pressed hazelnut oils during nine months of storage. Agronomy 2021, 11, 2045. [CrossRef]

5. Rivas, S.; Moure, A.; Parajó, J.C. Pretreatment of hazelnut shells as a key strategy for the solubilization and valorization of hemicelluloses into bioactive compounds. Agronomy 2020, 10, 760. [CrossRef]

6. Pérez-Armada, L.; Rivas, S.; González, B.; Moure, A. Extraction of phenolic compounds from hazelnut shells by green processes. J. Food Eng. 2019, 255, 1-8. [CrossRef]

7. Hoşgün, E.Z.; Bozan, B. Effect of different types of thermochemical pretreatment on the enzymatic hydrolysis and the composition of hazelnut shells. Waste Biomass Valorization 2020, 11, 3739-3748. [CrossRef]

8. Guney, M.S. Utilization of hazelnut husk as biomass. Sustain. Energy Technol. Assess. 2013, 4, 72-77. [CrossRef]

9. Arslan, Y.; Takaç, S.; Eken-Saraçoĝlu, N. Kinetic study of hemicellulosic sugar production from hazelnut shells. Chem. Eng. J. 2012, 185-186, 23-28. [CrossRef]

10. Özçelik, E.; Pekșen, A. Hazelnut husk as a substrate for the cultivation of shiitake mushroom (Lentinula edodes). Bioresour. Technol. 2007, 98, 2652-2658. [CrossRef]

11. Uzuner, S.; Sharma Shivappa, R.R.; Cekmecelioglu, D. Bioconversion of alkali pretreated hazelnut shells to fermentable sugars for generation of high value products. Waste Biomass Valorization 2017, 8, 407-416. [CrossRef]

12. Çöpür, Y.; Güler, C.; Taşçioğlu, C.; Tozluoğlu, A. Incorporation of hazelnut shell and husk in MDF production. Bioresour. Technol. 2008, 99, 7402-7406. [CrossRef] [PubMed]

13. Barbu, M.C.; Sepperer, T.; Tudor, E.M.; Petutschnigg, A. Walnut and hazelnut shells: Untapped industrial resources and their suitability in lignocellulosic composites. Appl. Sci. 2020, 10, 6340. [CrossRef]

14. Şencan, A.; Karaboyac1, M.; Kılıç, M. Determination of lead(II) sorption capacity of hazelnut shell and activated carbon obtained from hazelnut shell activated with $\mathrm{ZnCl}_{2}$. Environ. Sci. Pollut. Res. 2015, 22, 3238-3248. [CrossRef] [PubMed]

15. Cimino, G.; Passerini, A.; Toscano, G. Removal of toxic cations and $\mathrm{Cr}(\mathrm{VI})$ from aqueous solution by hazelnut shell. Water Res 2000, 34, 2955-2962. [CrossRef]

16. Kazemipour, M.; Ansari, M.; Tajrobehkar, S.; Majdzadeh, M.; Kermani, H.R. Removal of lead, cadmium, zinc, and copper from industrial wastewater by carbon developed from walnut, hazelnut, almond, pistachio shell, and apricot stone. J. Hazard. Mater. 2008, 150, 322-327. [CrossRef]

17. Kobya, M.; Demirbas, E.; Öncel, M.S.; Sencan, S. Adsorption kinetic models applied to nickel ions on hazelnut shell activated carbons. Adsorpt. Sci. Technol. 2002, 20, 179-188. [CrossRef]

18. Demirbas, E.; Dizge, N.; Sulak, M.T.; Kobya, M. Adsorption kinetics and equilibrium of copper from aqueous solutions using hazelnut shell activated carbon. Chem. Eng. J. 2009, 148, 480-487. [CrossRef]

19. Sert, S.; Çelik, A.; Tirtom, V.N. Removal of arsenic(III) ions from aqueous solutions by modified hazelnut shell. Desalin. Water Treat. 2017, 75, 115-123. [CrossRef]

20. Pehlivan, E.; Altun, T.; Cetin, S.; Iqbal Bhanger, M. Lead sorption by waste biomass of hazelnut and almond shell. J. Hazard. Mater. 2009, 167, 1203-1208. [CrossRef]

21. Demirbaş, E. Adsorption of cobalt(II) ions from aqueous solution onto activated carbon prepared from hazelnut shells. Adsorpt. Sci. Technol. 2003, 21, 951-963. [CrossRef]

22. Lewicka, K. Activated carbons prepared from hazelnut shells, walnut shells and peanut shells for high $\mathrm{CO}_{2}$ adsorption. Polish J. Chem. Technol. 2017, 19, 38-43. [CrossRef]

23. Contini, M.; Baccelloni, S.; Massantini, R.; Anelli, G. Extraction of natural antioxidants from hazelnut (Corylus avellana L.) shell and skin wastes by long maceration at room temperature. Food Chem. 2008, 110, 659-669. [CrossRef]

24. Yuan, B.; Lu, M.; Eskridge, K.M.; Isom, L.D.; Hanna, M.A. Extraction, identification, and quantification of antioxidant phenolics from hazelnut (Corylus avellana L.) shells. Food Chem. 2018, 244, 7-15. [CrossRef]

25. Yuan, B.; Lu, M.; Eskridge, K.M.; Hanna, M.A. Valorization of hazelnut shells into natural antioxidants by ultrasound-assisted extraction: Process optimization and phenolic composition identification. J. Food Process Eng. 2018, 41, 1-13. [CrossRef]

26. Esposito, T.; Sansone, F.; Franceschelli, S.; Del Gaudio, P.; Picerno, P.; Aquino, R.P.; Mencherini, T. Hazelnut (Corylus avellana L.) shells extract: Phenolic composition, antioxidant effect and cytotoxic activity on human cancer cell lines. Int. J. Mol. Sci. 2017, 18, 392. [CrossRef] [PubMed]

27. Surek, E.; Buyukkileci, A.O. Production of xylooligosaccharides by autohydrolysis of hazelnut (Corylus avellana L.) shell. Carbohydr. Polym. 2017, 174, 565-571. [CrossRef]

28. Midilli, A.; Rzayev, P.; Olgun, H.; Ayhan, T. Solar hydrogen production from hazelnut shells. Int. J. Hydrogen Energy 2000, 25, 723-732. [CrossRef] 
29. Midilli, A.; Dogru, M.; Howarth, C.R.; Ayhan, T. Hydrogen production from hazelnut shell by applying air-blown downdraft gasification technique. Int. J. Hydrogen Energy 2001, 26, 29-37. [CrossRef]

30. Hoşgün, E.Z.; Berikten, D.; Kıvanç, M.; Bozan, B. Ethanol production from hazelnut shells through enzymatic saccharification and fermentation by low-temperature alkali pretreatment. Fuel 2017, 196, 280-287. [CrossRef]

31. Fuso, A.; Risso, D.; Rosso, G.; Rosso, F.; Manini, F.; Manera, I.; Caligiani, A. Potential valorization of hazelnut shells through extraction, purification and structural characterization of prebiotic compounds: A critical review. Foods 2021, 10, 1197. [CrossRef]

32. Badalyan, S.; Zambonelli, A. The potential of mushrooms to develop healthy food and biotech products. In Fungi and Fungal Products in Human Welfare and Biotechnology; Satyanarayana, T., Deshmukh, S.K., Eds.; Springer Nature: Berlin/Heidelberg, Germany, 2022.

33. Royse, D.J.; Baars, J.; Tan, Q. Current overview of mushroom production in the world. In Edible and Medicinal Mushrooms: Technology and Applications; Zied, D.C., Pardo-Giménez, A., Eds.; John Wiley \& Sons Ltd.: Chichester, UK, 2017 ; pp. 5-13.

34. Vedder, J.C.; Van den Munckhof-Vedder, M. Modern Mushroom Growing 2020 Harvesting; Vedder, P.J.C., Ed.; Harvest House: Irvine, CA, USA, 2020.

35. Wang, L.; Li, J.Q.; Zhang, J.; Li, Z.M.; Liu, H.G.; Wang, Y.Z. Traditional uses, chemical components and pharmacological activities of the genus: Ganoderma P. Karst.: A review. RSC Adv. 2020, 10, 42084-42097. [CrossRef]

36. Di Piazza, S.; Benvenuti, M.; Damonte, G.; Cecchi, G.; Mariotti, M.G.; Zotti, M. Fungi and circular economy: Pleurotus ostreatus grown on a substrate with agricultural waste of lavender, and its promising biochemical profile. Recycling 2021, 6, 40. [CrossRef]

37. Pekşen, A.; Küçükomuzlu, B. Yield potential and quality of some Pleurotus species grown in substrates containing hazelnut husk. Pak. J. Biol. Sci. 2004, 7, 768-771. [CrossRef]

38. Yildiz, S.; Yildiz, Ü.C.; Gezer, E.D.; Temiz, A. Some lignocellulosic wastes used as raw material in cultivation of the Pleurotus ostreatus culture mushroom. Process Biochem. 2002, 38, 301-306. [CrossRef]

39. Coates, J. Interpretation of infrared spectra, a practical approach. In Encyclopedia of Analytical Chemistry; Meyers, R.A., Ed.; John Wiley \& Sons Ltd.: Chichester, UK, 2006; pp. 10815-10837.

40. Li, X.P.; Li, J.; Liu, H.; Wang, Y.Z. A new analytical method for discrimination of species in Ganodermataceae mushrooms. Int. J. Food Prop. 2020, 23, 227-240. [CrossRef]

41. Pin, M.W.; Park, E.J.; Choi, S.; Kim, Y.I.; Jeon, C.H.; Ha, T.H.; Kim, Y.H. Atomistic evolution during the phase transition on a metastable single NaYF4:Yb,Er upconversion nanoparticle. Sci. Rep. 2018, 8, 1-10. [CrossRef]

42. Bekiaris, G.; Tagkouli, D.; Koutrotsios, G.; Kalogeropoulos, N.; Zervakis, G.I. Pleurotus mushrooms content in glucans and ergosterol assessed by ATR-FTIR spectroscopy and multivariate analysis. Foods 2020, 9, 535. [CrossRef]

43. O'Gorman, A.; Downey, G.; Gowen, A.A.; Barry-Ryan, C.; Frias, J.M. Use of fourier transform infrared spectroscopy and chemometric data analysis to evaluate damage and age in mushrooms (Agaricus bisporus) grown in Ireland. J. Agric. Food Chem. 2010, 58, 7770-7776. [CrossRef]

44. Fornito, S.; Puliga, F.; Leonardi, P.; Di Foggia, M.; Zambonelli, A.; Francioso, O. Degradative ability of mushrooms cultivated on corn silage digestate. Molecules 2020, 25, 3020. [CrossRef]

45. Bekiaris, G.; Koutrotsios, G.; Tarantilis, P.A.; Pappas, C.S.; Zervakis, G.I. FTIR assessment of compositional changes in lignocellulosic wastes during cultivation of Cyclocybe cylindracea mushrooms and use of chemometric models to predict production performance. J. Mater. Cycles Waste Manag. 2020, 22, 1027-1035. [CrossRef]

46. Tryfinopoulou, P.; Chourdaki, A.; Nychas, G.J.E.; Panagou, E.Z. Competitive yeast action against Aspergillus carbonarius growth and ochratoxin A production. Int. J. Food Microbiol. 2020, 317, 108460. [CrossRef]

47. Sinclair, C.G.; Cantero, D. Fermentation modelling. In Fermentation a Practical Approach; McNeil, B.L., Harvey, M., Eds.; IRL Press: New York, NY, USA, 1989; pp. 65-112.

48. Oei, P. Mushroom Cultivation IV: Appropriate Technology for Mushroom Growers; ECO Consult Foundation: Amsterdam, The Netherlands, 2016.

49. Zhang, H.; Peng, J.; Zhang, Y.R.; Liu, Q.; Pan, L.Q.; Tu, K. Discrimination of volatiles of shiitakes (Lentinula edodes) produced during drying process by electronic nose. Int. J. Food Eng. 2020, 16, 1-13. [CrossRef]

50. Chang, S.T.; Lau, O.W.; Cho, K.Y. The cultivation and nutritional value of Pleurotus sajor-caju. Eur. J. Appl. Microbiol. Biotechnol. 1981, 12, 58-62. [CrossRef]

51. R Studio. Available online: https://www.rstudio.com (accessed on 6 February 2022).

52. Rahman, M.R.; Hamdan, S.; Lai, J.C.H.; Jawaid, M.; Yusof, F.A.; Bin, M. Physico-mechanical, thermal and morphological properties of furfuryl alcohol/2-ethylhexyl methacrylate/halloysite nanoclay wood polymer nanocomposites (WPNCs). Heliyon 2017, 3, e00342. [CrossRef] [PubMed]

53. Mohebby, B. Attenuated total reflection infrared spectroscopy of white-rot decayed beech wood. Int. Biodeterior. Biodegrad. 2005, 55, 247-251. [CrossRef]

54. Popescu, C.M.; Popescu, M.C.; Vasile, C. Structural changes in biodegraded lime wood. Carbohydr. Polym. 2010, 79, 362-372. [CrossRef]

55. Singh, S.; Harms, H.; Schlosser, D. Screening of ecologically diverse fungi for their potential to pretreat lignocellulosic bioenergy feedstock. Appl. Microbiol. Biotechnol. 2014, 98, 3355-3370. [CrossRef]

56. Huang, X.; Kocaefe, D.; Kocaefe, Y.; Boluk, Y.; Pichette, A. Study of the degradation behavior of heat-treated jack pine (Pinus banksiana) under artificial sunlight irradiation. Polym. Degrad. Stab. 2012, 97, 1197-1214. [CrossRef] 
57. Bekiaris, G.; Lindedam, J.; Peltre, C.; Decker, S.R.; Turner, G.B.; Magid, J.; Bruun, S. Rapid estimation of sugar release from winter wheat straw during bioethanol production using FTIR-photoacoustic spectroscopy. Biotechnol. Biofuels 2015, 8, 1-12. [CrossRef]

58. Fan, M.; Dai, D.; Huang, B. Fourier transform infrared spectroscopy for natural fibres. Fourier Transform-Mater. Anal. 2012, $3,45-68$.

59. De Rosa, I.M.; Kenny, J.M.; Puglia, D.; Santulli, C.; Sarasini, F. Morphological, thermal and mechanical characterization of okra (Abelmoschus esculentus) fibres as potential reinforcement in polymer composites. Compos. Sci. Technol. 2010, 70, 116-122. [CrossRef]

60. Pandey, K.K.; Pitman, A.J. FTIR studies of the changes in wood chemistry following decay by brown-rot and white-rot fungi. Int Biodeterior. Biodegrad. 2003, 52, 151-160. [CrossRef]

61. Zervakis, G.I.; Bekiaris, G.; Tarantilis, P.A.; Pappas, C.S. Rapid strain classification and taxa delimitation within the edible mushroom genus Pleurotus through the use of diffuse reflectance infrared Fourier transform (DRIFT) spectroscopy. Fungal Biol. 2012, 116, 715-728. [CrossRef] [PubMed]

62. Choong, Y.K.; Sun, S.Q.; Zhou, Q.; Ismail, Z.; Rashid, B.A.A.; Tao, J.X. Determination of storage stability of the crude extracts of Ganoderma lucidum using FTIR and 2D-IR spectroscopy. Vib. Spectrosc. 2011, 57, 87-96. [CrossRef]

63. Mohaček-Grošev, V.; Božac, R.; Puppels, G.J. Vibrational spectroscopic characterization of wild growing mushrooms and toadstools. Spectrochim. Acta Part A Mol. Biomol. Spectrosc. 2001, 57, 2815-2829. [CrossRef]

64. Das, B.; Rajkonwar, J.; Jagannath, A.; Raul, P.K.; Deb, U. Infra-red spectra of different species of cultivated oyster mushrooms: Possible tool for identifying bioactive compounds and establishing taxonomic linkage. Def. Life Sci. J. 2020, 5, 118-124. [CrossRef]

65. Melanouri, E.M.; Dedousi, M.; Diamantopoulou, P. Cultivating Pleurotus ostreatus and Pleurotus eryngii mushroom strains on agro-industrial residues in solid-state fermentation. Part II: Effect on productivity and quality of carposomes. Carbon Resour. Convers. 2022, 5, 52-60. [CrossRef]

66. Şenol, H. Biogas potential of hazelnut shells and hazelnut wastes in Giresun City. Biotechnol. Rep. 2019, 24, e00361. [CrossRef]

67. Kaya, N.; Y1ld1z, Z.; Ceylan, S. Preparation and characterisation of biochar from hazelnut shell and its adsorption properties for methylene blue dye. J. Polytech. 2018, 21, 765-776. [CrossRef]

68. Kumla, J.; Suwannarach, N.; Sujarit, K.; Penkhrue, W.; Kakumyan, P.; Jatuwong, K.; Vadthanarat, S.; Lumyong, S. Cultivation of mushrooms and their lignocellulolytic enzyme production through the utilization of agro-industrial waste. Molecules $\mathbf{2 0 2 0}$ 25, 2811. [CrossRef]

69. Stamets, P. Growing Gourmet and Medicinal Mushrooms; Ten Speed Press: Berkeley, CA, USA, 2000.

70. Tamaki, Y.; Mazza, G. Rapid determination of lignin content of straw using Fourier transform mid-infrared spectroscopy. J. Agric. Food Chem. 2011, 59, 504-512. [CrossRef] [PubMed]

71. Del Río, J.C.; Rencoret, J.; Prinsen, P.; Martínez, Á.T.; Gutiérrez, A.; Ralph, J. Structural characterization of wheat straw lignin Evidence for a novel monomer in grasses. Cons. Super. Investig. Científicas 2013. Available online: https://digital.csic.es/ bitstream/10261/86427/1/JCdelRio-17ISWFPC-proceeding.pdf. (accessed on 16 December 2021).

72. Pettersen, R.C. The chemical composition of wood. In The Chemistry of Solid Wood; American Chemical Society: New York, NY, USA, 1984; pp. 57-126.

73. Le Floch, A.; Jourdes, M.; Teissedre, P.L. Polysaccharides and lignin from oak wood used in cooperage: Composition, interest, assays: A review. Carbohydr. Res. 2015, 417, 94-102. [CrossRef] [PubMed]

74. Vinciguerra, V.; Spina, S.; Luna, M.; Petrucci, G.; Romagnoli, M. Structural analysis of lignin in chestnut wood by pyrolysis-gas chromatography/mass spectrometry. J. Anal. Appl. Pyrolysis 2011, 92, 273-279. [CrossRef]

75. Madeira, J.V.; Contesini, F.J.; Calzado, F.; Rubio, M.V.; Zubieta, M.P.; Lopes, D.B.; de Melo, R.R. Agro-industrial residues and microbial enzymes: An Overview on the eco-friendly bioconversion into high value-added products. In Biotechnology of Microbial Enzymes: Production, Biocatalysis and Industrial Applications; Elsevier, Inc.: London, UK, 2017; pp. 475-511; ISBN 9780128037461.

76. Jurak, E.; Patyshakuliyeva, A.; De Vries, R.P.; Gruppen, H.; Kabel, M.A. Compost grown Agaricus bisporus lacks the ability to degrade and consume highly substituted xylan fragments. PLoS ONE 2015, 10, e0134169. [CrossRef]

77. Nandni, S.; Mishra, S. Crop room studies in relation to yield potential of Lentinula edodes strains on wheat straw. J. Hill Agric. 2018, 9, 124. [CrossRef]

78. Kalmiş, E.; Sargin, S. Cultivation of two Pleurotus species on wheat straw substrates containing olive mill waste water. Int. Biodeterior. Biodegrad. 2004, 53, 43-47. [CrossRef]

79. Ćilerdžić, J.L.; Vukojević, J.B.; Klaus, A.S.; Ivanović, Ž.S.; Blagojević, J.D.; Stajić, M.M. Wheat straw-A promissing substrate for Ganoderma lucidum cultivation. Acta Sci. Pol. Hortorum Cultus 2018, 17, 13-22. [CrossRef]

80. Ritz, K.; Crawford, J.W. Colony development in nutritionally heterogeneous environments. In The Fungal Colony; Gow, N.A.R., Robson, G.D., Gadd, G.M., Eds.; Cambridge University Press: Cambridge, UK, 1999; pp. $49-74$.

81. Bruhn, J.; Hall, M. Growing Shiitake Mushrooms in an Agroforestry Practice. Available online: https://centerforagroforestry.org/ wp-content/uploads/2021/05/af1010 (accessed on 16 December 2021).

82. Zivanovic, S.; Busher, R.W.; Kim, K.S. Textural changes in mushrooms (Agaricus bisporus) associated with tissue ultrastructure and composition. J. Food Sci. 2000, 65, 1404-1408. [CrossRef] 